\title{
HOW A CHOICE OF THE LEGAL FORM OF GARAGES AFFECTS ON SALE AND MANAGEMENT OF THEM
}

\author{
IWONA SZYMCZAK \\ University of Szczecin, Faculty of Management and Economics of Services, POLAND \\ e-mail: iwona.s1111@gmail.com
}

\author{
\begin{tabular}{l|l} 
RECEIVED & 6 November 2018
\end{tabular} \\ ACCEPTED $\quad 3$ December 2018 \\ JEL \\ CLASSIFICATION \\ $\mathrm{K} 11$
}

KEYWORDS co-ownership, condominium, garage, separate commercial premises

ABSTRACT The legislator gave to the building constructor the possibility to choose a legal form of garage in condominium. This decision brings important consequences for a potential buyer of garage. It refers to selling this garage separately and the manner of management of it. The main subject of this article is the presentation of varies legal forms of a garage under the Polish law and legal consequences, which are connected with the choice each of these form. The main goal of this paper is pointing out the differences in management of garages because of their forms. A specific goal is an explanation, which form of garage may be managed by the community of owners, but which of them, shall be managed by owners themselves. In last section of this paper, there is a legal analysis of the case-law. One of judgment state that a housing community may "take over" management of a garage, which is an separate premises co-owned only by some owners of residential premises. It is contentious, so in last point of this paper is explained, why a housing community cannot "take over" management of a such garage.

\section{Introduction}

In Polish law, there is a freedom for the developer to create the structure of condominium. He decides about the structure of common property, especially he can construct garages in varies legal form. According to the Act on Ownership of Premises (called later: AOP) four legal forms of garages should be distinguished (Gniewek, 2008, p. 16). Firstly, a garage may be a separate commercial premises belonging to one owner (art. 2 (1) AOP). Secondly, 
a garage may be a separate commercial premises covered by co-ownership, in which each of co-owners has a defined fraction and is entitled to exclusive use of allocated parking space on the basis of the division of qouad usum (art. 198 of the Civil Code, called later: CC, in relation to art. 2 (1) AOP). Thirdly, a garage may have the status of a room belonging to an separate dwelling (art. 2 (4) AOP). Fourthly, a garage may be part of a common property, in which it has been allocated the right for exclusive use by one of owners (art. 3 (2) AOP).

The main goal of this paper is pointing out, which rules as to selling and as to management, shall be applied as to each form of garage.

Out of four legal form of garage, two of them, there are no possibility to sale of a garage without a simultaneous sale of a dwelling premises with which, it is connected. As to rules of management of garages, the most problems concern how to manage a garage being a separate premises, which is the object of co-ownership belonging only to some owners of apartments. For these object shall be distinguished, firstly, "an internal management", which is covers issues inside the garage space, secondly, "an external management", which covers issues relating the common property.

\section{Common property and neighboring properties}

When explaining issues relating the legal status of a garage, the first distinction must be made regarding to their location. They are either within or outside the common property (as a neighboring property). As it was mentioned before, there are four legal forms of garages. One of them is located in a common property, but others are outside it (they are neighboring properties). Before I go to the details of this issue, it is necessary to present the general structure of a common property and its neighborhood. The common property is a land and part of building after the apartments have been separated. The criterion of identification for common property is a record in Land and Mortgage Register. (Drozd, 1994, p. 36). As to a scope of this property, a legal presumption can be made that a part of a common property is, what has not been clearly included to a separate ownership of premises (Szymczak, 2010 , s. 63). Despite the literal wording of art. 3 (2) AOP, the common property includes its parts covered by the quoad usum division (Watrakiewicz, 2002, p. 643).

As far as the neighboring properties to the common property are concerned, they are land properties, which are adjacent to it, and its "internal neighboring properties", which are located inside a building. The common property is adjacent to separate dwellings and premises for other purposes, both horizontally and vertically. In the first case, when the common property (as a land property) neighbors other land properties, problems will arise, when the ownership status, especially the structure of shares in the co-ownership of the neighboring property is similar (but not identical!) to the ownership structure of shares in the common property. In practice the most problems appear in a case, when some owners of the premises (but not all) are co-owners of the land adjacent to the common property. However, the legal classification is clear, if there is no identical structure of share, it precludes the taking this property for common management by housing community. It was stated in the resolution of the High Court of 20.11.2009, III CZP 95/09. As to the "internal" neighboring with other apartments, the situation looks clear, because in accordance with art. 2 (5) AOP these apartments with the belonging rooms shall be marked on the map of the building. 


\section{Garage as part of a common property}

In this point, I will consider the first case, in which, a garage is situated on common property and one of coowner has the right for exclusive use of it. If developer decides to locate garage on common property, it may be in the open space or inside a building. The parking areas located on the ground (in open space) should always have such a legal status. However, when it comes to setting a such form of garage inside a building, it is optional. These forms may occur in the geodetic-architectural sense as a marked place on the ground surface (in the open space) or inside the building, a place separated by lines on the floor or fences (boxes).

When the garage is located on common property, in this case, the garage (parking space) belongs to all coowners of the according to the their shares in the common property, but one of co-owners has an right to exclusive use. The structure of share in co-ownership of the common real estate does not change, however the only one co-owner uses a parking space or box located on the ground or in a building on the basis of the right to exclusive use of it.

The garage as the right to exclusive use of part of the common property arises on the basis of agreement of all co-owners. This contract is called an agreement on setting out the new way of use of common thing (it is called: the division qouad usum). In the doctrine, there is a view that the consent of all co-owners is necessary for its conclusion (Warciński, 2011, p. 36; Rudnicki, 2006, p. 267; Ignatowicz, 1972, p. 528; Biernat, 2007, p. 603). This contract does not require any special form, and the written form should be for evidence purposes only. On its basis no property right arises, but it is, in the legal sense, a new way of organizing the rules of using common real estate (Gniewek, 2013, p. 603). This contract should be concluded between all co-owners, because on its power the right-holder obtains the right to exclusive use of this part of the common real estate, and other co-owners are obliged not to use it. If the contract has been concluded for an indefinite period, it may be terminated in accordance with the general rules for terminating contracts for continuous service (Warciński, 2011, p. 46). The owners of the premises who signed it are bound by the provisions of such an agreement. However, a new purchaser of premises not being a party to this agreement, is not bound by it, unless the conditions referred to in art. $221 \mathrm{CC}$. are applied. For this reason, in order to extend the effectiveness of such an agreement with respect to new purchasers, who are not parties to this contract, its provisions should be entered in the Land and Mortgage Register (art. 16 (2) point 3 Act of Land Register).

The contrary view to this one, which mentioned above, was presented by the High Court in the resolution of 19.07.2007, III CZP 59/07. The Court stated that one of the co-owner may use the common parts of the building in the more intensive scope than his or her share, on basis of an agreement concluded by him or her with the housing community.

Other issue referring to legal form of a garage is the conveyance of this right. The owner has the main right, which is the separate ownership of the premises and a share in common property with exclusive right for usage. Therefore, he or she cannot dispose of it independently, but as a bundle of rights. Z. Radwański pointing out art. $50 \mathrm{CC}$, confirms that rights belonging to property are considered to be part of this real property right. In other words: they are "absorbed" by property and the need for their individualization disappears (1968, p. 95). The same idea refers the right to exclusive use of parking space. This means that it is not possible to sell a only garage as the right for exclusive use, without the residential premise (Weiss, 2018, p. 125).

The last point is the cost of maintaining this parking place or boxes being a part of common property. There is no doubt that in the economic sense the co-owner entitled to an exclusive use derives full benefit from the exploitation this part of the property allocated to him or her for usage. Other co-owners have the ban on using this part. However, 
according to art. 12 (2) AOP, costs of maintaining and real estate tax are imposed on all co-owners. The above provision should be improved in such a way, that the holder of exclusive right is burdened with the higher payment.

\section{Legal forms of garages located outside the common property General remarks}

In the previous point, it was described the legal form of the garage, which is a part of the common property. In this point, I will deal with the legal structures of the garage located outside the ownership structure of the common property (it is a garage as an adjacent property). These legal constructions are: a garage as a room belonging to a dwelling premises (1) and a garage as a separate commercial premises for another purpose (2). There are significant differences between these model solutions mentioned in point 1 and point 2 . As to point 2 there is no possibility of selling right to garage without selling a main right.

As to point 2, it must be distinguished that this form has two sub-categories. It may be either the object of ownership of one owner or the object of co-ownership, when each co-owner is entitled to this share in the coownership together with the right to exclusive use of a part of it, in particularly, a box or place (Drozd, 1994, p. 34).

\section{Gapage as a belonging room}

One of the legal forms, in which a garage can be set out, is a room belonging to a dwelling premises (art. 2 (4) AOP). It is qualified as part of the residential premises. The belonging room is a space which may adhere to the premises in a physical sense, but it is not necessary (Bończak-Kucharczyk, 2016, s. 26). It is also allowed that it do not need to be directly adhered to apartment or it may be located within the real estate ground outside the building (Watrakiewicz, 2002, p. 148 ). Its area is included to the total area of the apartment, on basis of which, the share in the common property is established (art. 3 (3) AOP). When we concern the acquisition of this right, first of all, we can distinguish a purchase from a first owner (a building constructor) and a purchase on the secondary market. In first case, the developer has more freedom to add or not the belonging room to apartment, but he has to reserve in advance "free" rooms, which will be jointed to apartments (Gniewek, 2008, p. 28). In second case, this belonging room is an essential element of sale contract of residential apartment. It impossible to sell apartment without it. As I mentioned above, selling the garage as belonging room to the premises is, as the principle, impossible. The existing garage belonging to the apartment can be sold only together with the main objecte. Although there is one exception for that, which consists in a dislocation of this room only between owners of separate premises within one condominium (Strzelczyk, 2015, p. 78). It is made on the basis of an agreement between these co-owners (Gniewek, 2008, p. 28). However, in this case, it is necessary to adjust the size of the shares of both owners performing this legal act (Bończak-Kucharczyk, 2016, p. 49). The next exception of independent dislocation of garage is detachment of a garage from the common property and including it as a room belonging to the premises. However, such an operation requires the consent of all co-owners, because it decreases the content of the common property.

\section{Garage as a separate commercial premises}

\section{General remarks}

As far as the garage as the separate premises belonging to one owner is concerned, the rules for sale of them are the same as for owners of residential premises (such a conclusion can be deduced from art. 4 (1) AOP, in 
which the legislator grants all owners equal rights and the duties, regardless of the purpose of the premises (see one exception for that, which is stipulated in Art. 12 (3) AOP). As general rule is that the owner of the garage, may transfer his ownership right in any time.

More legal complications appear when the garage is covered by a co-ownership. Each of its co-owners has own share and right for exclusive use of a part of area or box in garage. However, when it comes to the rules of transferring of such a right, comparing it to the first legal model, in which the owner has full ownership of the premises, in the second case the co-owner can freely dispose his share (art. $198 \mathrm{CC}$ ). This results from the nature of the co-ownership which is the ownership right "divided" into shares. On the one hand, we have a homogeneous object of ownership, but on the other hand, each co-owner has own share with an exclusive right for use of a part of the property. Management of the object covered by co-ownership takes place according to the Civil Code (art. 195 CC). Additionally, each co-owners of garage has own share in common property (condominium), to which The Act on Ownership of Premises is applied.

Therefore, it is necessary to distinguish the management activities undertaken by the co-owners regarding the common real estate ("external" management) and the management activities related to the main object, which is a garage ("internal" management).

\section{"External" management of the garage as the premises with multi-parking places}

As regards the external management, in accordance with art. 1a AOP, co-owners of premises has the same right as the full owner of premises. It relates to co-owners of garage. Therefore, each co-owner of commercial premises, is the holder of a fractional share in common property and he has all the duties and membership rights in the housing community. In practice, this means that each of them has not only an independent property right (share in co-ownership of the premises), but also corporate rights in the housing community, and therefore he or she is a independent participant of managing process and he has own right to vote at the meetings of the owners. The weight of vote for each of the co-owners, is calculated according to art. 3 (3a) AOP.

\section{"Internal" management of premises constituting a multi-parking places}

In the case, where premises for other purposes (including a garage) is covered by co-ownership, the management of its space (inside) is based on the provisions of the Civil Code on fractional co-ownership (art. 195 CC), but not on the provisions of the Act on Ownership of Premises. Therefore, the majority of its coowners, calculated according to the size of the share (art. 204 CC), is required to make decisions on ordinary management matters (art. 201 CC). Day-by-day management activities may refer to making decisions regarding current affairs (e.g. cleaning contracts, contract for maintenance services), whereas the contracts on major repairs or incurring a big amount of loan for this activities, that exceed ordinary management matters require the consent of all co-owners of the garage (art. 199 CC).

Thus, the housing community doesn't have any statutory competence to manage the separate ownership of the garage. Such a conclusion results from the judgment of the High Court of 14 March 2013, I CSK 379/12, in which the Court, dismissing the appeal by the housing community, explained that "the housing community cannot claim damages regarding the subject of the separate ownership when only some co-owners may benefit from it. So, a consequence of this judgment, is the conclusion that the housing community cannot take over this property for management. 


\section{Taking over management of garages by the housing community in case-law}

It was mentioned above, that it is a disputable issue showing discrepancies in case law, whether it is possible to take over by the housing community the management of a garage that is a separate premises belonging only to some members of housing community. As an example I will present two opposite judgments. The first is the judgment of the High Court of 11.05.2016, I CSK 415/15, in which the Court stated that the Housing Community could not adopt a resolution containing a total calculation of maintenance costs of real estate located beyond borders of common property. Thus, the High Court confirmed the general principle that a housing community has no competence to manage a neighboring real estate.

A similar view was confirmed by High Court in the resolution from 21.12.2007, III CZP 65/07. In the justification it was stated that "the legal provisions of the Act on the ownership of premises create legal grounds for assuming that the ability of the housing community has been limited only to the rights and obligations related to the management of common property. A similar view was in the judgment of 8.10.2008, V CSK 143/08 and resolution of 24.11.2006, III CZP 97/06, (Biul SN 2006, no. 11). Court said that the scope of the legal capacity of the housing community is limited to the acquisition of rights and occurring obligations related only to the management of the common property. Other obligations cannot arise because they would go beyond the statutory scope of the community's legal capacity. In addition, the High Court in the judgment of 8.10.2008, V CSK 143/08, pointed out the essence of the problem connected with art. $17 \mathrm{AOP}$, in which the responsibility of the housing community and its members is limited to scope of debts arising from management of "common real estate".

Unfortunately, the opposite view was shown in the judgment of the High Court of 26.06.2015, I CSK 312/14. According to it, a housing community can also make decisions referring to real estate matters, which formally doesn't belong to it, but it is the subject of co-ownership of only few members of community (not all members).

The last judgment of the High Court is contentious. The housing community does not have statutory competences to manage the neighboring property, since it is a real estate (land or separated ownership to premises), which structure of shares in a co-ownership is not equal with the co-ownership structure of common property. Such a property is "neighboring property". Housing community, by adopting a resolution based on the majority of owners (Art. 23 (2) AOP), breaches the provisions of the Act on Ownership of Premises. There is no a such activity in the scope of its tasks pointed out in art. 22 (3) AOP. What is more, even if we agree with the High Court's judgment, than the effect of such a solution will be still unclear. In my opinion the resolution has only an internal effect. It can only authorize the housing community to management of it, but there is no external result, which is taking over of the management of the property. For effectiveness of a external result a conclusion of a contract between a housing community and co-owners of a garage property is needed. This requirement comes out from art. 185 (2) Act on Real Estate Management. According to it, a contract shall be concluded between a professional manager and an owner of real property. In this case, the parties of such an agreement should be a housing community as a real estate manager and co-owners of the garage (see judgment of 3.06.2015, I ACa 95/15 in Katowice).

\section{Conclusions}

The diversity of legal forms of garages makes difficult to interpret the rules of managing of garage. But the conclusion comes out from this paper is that the housing community can only manage the garage, which is situated on common property. The wrong practice is when the housing community is managing a real estate (garage) belonging to other entities, when only some of them are also its members. This applies to garage that is 
a separate commercial premises covered by co-ownership. It cannot be accepted the legal construction of "taking over to management" of neighboring real estate under the legal basis of taking resolution by the housing community (majority of votes).

Then, the simplest solution is the contract between co-owners of a garage and a professional manager of real properties. Entrusting the management directly to the professional manager without engaging the housing community as an intermediate link, is a more clear way of management.

\section{References}

Act of 24 June 1994 on the Ownership of Premises. Uniform text: Journal of Law from 2018 item 716), called: AOP.

Act on Real Estate Management. Uniform text: Journal of Law from 2018, item 121; 50,650, 1000, called: AREM.

Biernat, J. (2007). Glosa krytyczna do uchwały. Monitor Prawniczy, 11.

Bończak-Kucharczyk, E. (2016). Własność lokali i wspólnoty mieszkaniowe. Komentarz. Warszawa: Wolters Kluwer.

Drozd, E. (1994). Ustanowienie odrębnej własności lokali. Rejent, 12.

Gniewek, E. (2008). O nabywaniu przez właścicieli lokali pomieszczeń przynależnych - po ustanowieniu odrębnej własności lokali. Rejent, 5, 9-29.

Gniewek, E. (ed.) (2013). System Prawa Prywatnego, t.3, Prawo rzeczowe. Warszawa: C.H. Beck.

Ignatowicz, J. (1972). Kodeks cywilny. Komentarz, t. 1, Księga I - Cześć ogólna. Księga II - Własność i inne prawa rzeczowe (ed. Resich). Warszawa: PWN.

Polish Civil Code from 1964. Uniform text: Journal of Law from 2018, item 1025, called: CC.

Rudnicki, S. (2006). Komentarz do Kodeksu cywilnego. Własność i inne prawa rzeczowe. Warszawa: Wolters Kluwer Polska.

Strzelczyk, R. (2015). Własność lokali. Komentarz. Warszawa: C.H. Beck.

Szymczak, I. (2010). Nieruchomość wspólna a podział quoad usum. Opolskie Studia Administracyjno-Prawne, z. VII, 61-71.

Warciński, M. (2011). Podział rzeczy quoad usum. Państwo i Prawo, 35-43.

Watrakiewicz, M. (2002). Nieruchomość wspólna według ustawy o własności lokali. Kwartalnik Prawa Prywatnego, 3.

Watrakiewicz, M. (2005). Glosa do postanowienia SN z 19.05.2004 r. I CK 696/03. Rejent, 12, 144-151.

Weiss, M. (2018). Zbycie prawa do miejsca parkingowego ukształtowanego w ramach podziału quoad usum. Rejent, 10.

Case-law (www.sn.pl/orzecznictwo/SitePages/Najnowsze_orzeczenia.aspx).

Judgment of High Court of 24.11.2006 (III CZP 97/06, Biul. SN 2006, nr 11).

Judgment of High Court of SN 21.12.2007, III CZP 65/07.

Judgment of High Court of 8.10.2008, V CSK 143/08 (OSN 2008, nr 7-8, poz. 69).

Judgment of High Court of 20.11.2009, III CZP 95/09 (OSNC 2010/ 5/73).

Judgment of the High Court of 14.03.2013, I CSK 379/12.

Judgment of High Court of 26.06.2015, I CSK 312/14.

Judgment of High Court of 11.05.2016, I CSK 415/15.

Judgment of High Court of 3.06.2015, I ACa 95/15 w Katowicach (LEX nr 1754179).

Cite this article aS: Szymczak, I. (2018). How a choice of the legal form of garages affects on sale and management of them. European Journal of Service Management, 4 (28/1), 313-319. DOI: 10.18276/ejsm.2018.28/1-39. 